\title{
Transformation of iodate to iodide in marine phytoplankton driven by cell senescence
}

\author{
K. Bluhm ${ }^{1, *}$, P. $\operatorname{Croot}^{1}$, K. Wuttig ${ }^{1}$, K. Lochte ${ }^{2}$ \\ ${ }^{1}$ IFM-GEOMAR, Leibniz Institute for Marine Sciences, Marine Biogeochemistry, Westshore Building, \\ Duesternbrooker Weg 20, 24105 Kiel, Germany
}

${ }^{2}$ Alfred-Wegener-Institute for Polar and Marine Research, Am Handelshafen 12, 27570 Bremerhaven, Germany

\begin{abstract}
Previous studies have suggested that phytoplankton play an important role in the biogeochemical cycling of iodine, due to the appearance of iodide in the euphotic zone. Changes in the speciation of iodine over the course of the growth cycle were examined in culture media for a variety of phytoplankton taxa (diatoms, dinoflagellates and prymnesiophytes). All species tested showed the apparent ability to reduce iodate to iodide, though production rates varied considerably among species

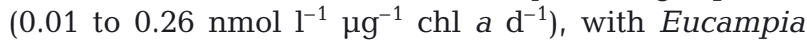
antarctica the least and Pseudo-nitzschia turgiduloides the most efficient iodide producers. Production was found to be species specific and was not related to biomass (indicated by e.g. cell size, cell volume, or chl a content). In all species, except for the mixotrophic dinoflagellate Scrippsiella trochoidea, iodide production commenced in the stationary growth phase and peaked in the senescent phase of the algae, indicating that iodide production is connected to cell senescence. This suggests that iodate reduction results from increased cell permeability, which we hypothesize is due to subsequent reactions of iodate with reduced sulphur species exuded from the cell. A shift from senescence back to the exponential growth phase resulted in a decline in iodide and indicated that phytoplankton-mediated oxidation of iodide to iodate was likely to be occurring. Iodide production could not be observed in healthy cells kept in the dark for short periods. Bacterial processes appeared to play only a minor role in the reduction of iodate to iodide.
\end{abstract}

KEY WORDS: Iodine speciation - Iodide - Iodate · Antarctic diatoms - Nitrate reductase - Glutathione · Sulphur species $\cdot$ Cell senescence

Resale or republication not permitted without written consent of the publisher

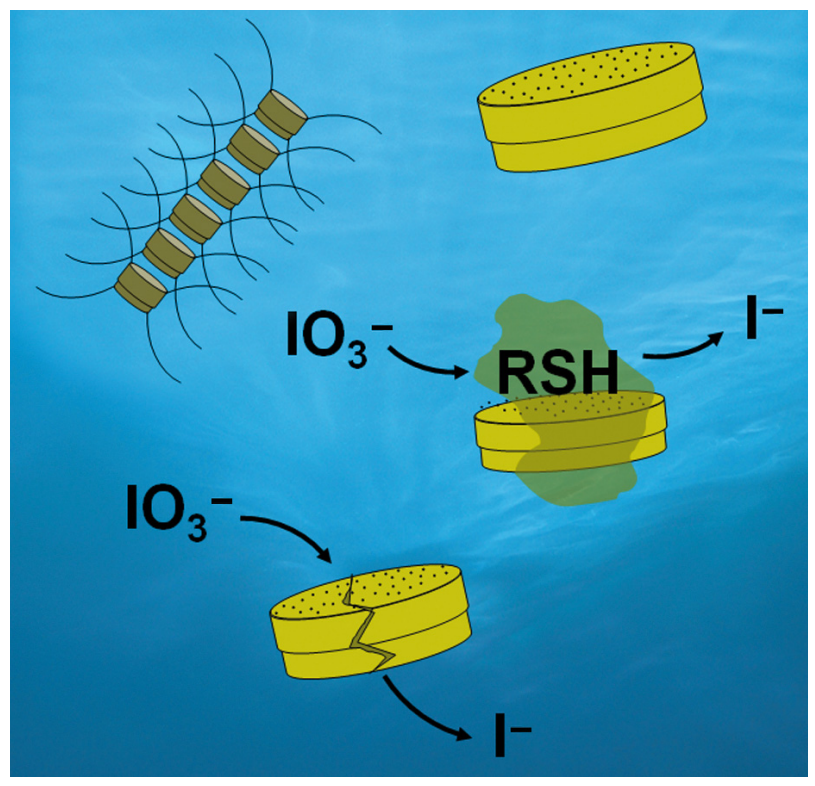

Intracellular material (RSH-thiols) leaking from phytoplankton cells converts iodate to iodide. RSH: organic sulphur species

Diagram: Peter Croot \& Linn Hoffmann

\section{INTRODUCTION}

Iodine has recently been identified as a potential key element involved in climate change, as iodide reacts rapidly with $\mathrm{O}_{3}$, and is believed to be a major sink for atmospheric $\mathrm{O}_{3}$ at the sea surface (Garland et al. 1980). This reaction forms HOI and $\mathrm{I}_{2}$, and has also been suggested as a source of organic halogens (RI) (Martino et al. 2009). RI released from the sea to the atmosphere will undergo photolysis and oxidation in the atmosphere to form IO (Saiz-Lopez et al. 2007, Schonhardt 
et al. 2008), which is the major source of new particles in the atmosphere (von Glasow 2005), with the potential to influence cloud properties and hence the climate (O'Dowd \& de Leeuw 2007). In coastal regions, $I_{2}$ can also directly be released into the atmosphere by kelp and seaweed and reacts here to equally form IO. Thus, information on the cycling of iodine species in the ocean is important for assessing the impact of iodine in tropospheric ozone chemistry and for climate dynamics. While biology clearly plays a role in the marine iodine cycle, it is still not clear what the link between biological processes and the speciation of iodine in seawater is.

Iodine exists principally in open seawater as the inorganic redox forms iodate $\left(\mathrm{IO}_{3}^{-}\right)$and iodide $\left(\mathrm{I}^{-}\right)$, with a total concentration of 400 to $500 \mathrm{nmol} \mathrm{l}^{-1}$ in most oceanic regions. While iodate predominates in the deep ocean (Tsunogai \& Sase 1969, Elderfield \& Truesdale 1980, Farrenkopf et al. 1997), significant amounts of iodide are found in surface and near-bottom layers (Kennedy \& Elderfield 1987, Wong 1991, Luther et al. 1995). The interconversion of the redox couple iodate-iodide within the euphotic zone, together with the biophilic nature of iodine, has given rise to the idea that iodine speciation is linked to primary productivity (Sugawara \& Terada 1967, Tsunogai \& Henmi 1971, Elderfield \& Truesdale 1980, Moisan et al. 1994, Campos et al. 1996, Truesdale et al. 2000). The evidence for a link between iodate reduction and primary productivity came from field observations that suggested surface iodate decreases towards the productive equatorial regions (Tsunogai \& Henmi 1971, Jickells et al. 1988, Campos et al. 1996, Truesdale et al. 2000). Additional evidence was found in distinct correlations between iodate and macronutrient concentrations at several stations (Elderfield \& Truesdale 1980, Truesdale 1994, Campos et al. 1999). However, a clear link between primary productivity and the reduction of iodate has yet to be shown, and other explanations for the global distribution of iodate have been put forward, e.g. vertical mixing (Truesdale et al. 2000) and regional differences in phytoplankton community (Campos et al. 1999). Although abiotic mechanisms have been proposed for the reduction of iodate and the consequent formation of iodide (Spokes \& Liss 1996), the presence of iodide in surface waters is typically ascribed to biological activity (Campos et al. 1996).

Laboratory experiments on the influence of phytoplankton on iodine speciation have led to varying results. In the first such work of this type, Sugawara \& Terada (1967) examined iodide and iodate assimilation by the marine diatom Navicula sp. using radiotracers. In their work this diatom preferentially assimilated iodide over iodate and appeared to accomplish the conversion of iodide to iodate and vice versa. A recent radiotracer study into the accumulation rates of iodide and iodate by a number of phytoplankton batch culture experiments confirmed this preference for iodide over iodate in the uptake by phytoplankton, but also showed large differences between species (de la Cuesta \& Manley 2009). Other laboratory experiments with phytoplankton cultures have shown significant iodate uptake rates (Moisan et al. 1994). The conversion of iodate to iodide has been shown in batch culture at ambient iodate concentrations (Wong et al. 2002, Chance et al. 2007). Much of this work has been carried out to test the hypothesis put forward by Tsunogai \& Sase (1969) that nitrate reductase can reduce iodate to iodide in the ocean when nitrate is limiting. This hypothesis grew out of the earlier finding by Egami \& Sato (1947) that nitrate reductase is capable of reducing iodate under physiological conditions. Contrastingly, a number of studies found no relationship between iodine and biological activity or only observed iodide increases in phytoplankton cultures at iodate concentrations 10-fold greater than those naturally found (Truesdale 1978b, Butler et al. 1981, Waite \& Truesdale 2003). A detailed study (Waite \& Truesdale 2003) into the nitrate reductase hypothesis in which cells were grown on ammonia and the enzyme was deactivated by replacing molybdenum with tungsten in the growth media showed that iodate reduction was relatively insensitive to the function of nitrate reductase.

Experiments examining changes in iodine speciation have been predominantly performed with temperate, tropical and, to a lesser extent, cold water species, with Antarctic species having been totally neglected. Surface iodide concentrations are low in the Southern Ocean, although with some surface maxima, which are possibly due to biological activity (Campos et al. 1999, Truesdale et al. 2000, K. Bluhm et al. unpubl.). During an Antarctic mesocosm experiment carried out by Truesdale et al. (2003), no changes in iodine speciation were observed. The authors suggested that the large, chain-forming diatom Thalassiosira antarctica, which dominated the mesocosm blooms, is unable to perform the reduction of iodate to iodide. As phytoplankton blooms in polar regions typically exist over more than $30 \mathrm{~d}$ (Boyd 2004), the $25 \mathrm{~d}$ duration of their mesocosm experiment apparently did not catch the end of the bloom. The importance of this lies in the observation from an earlier field study conducted over a seasonal cycle in the Mediterranean by Tian et al. (1996), which indicated that iodate reduction was related to regenerated production and not primary production directly. Thus, the mesocosm work of Truesdale et al. (2003) may not have run long enough to observe the critical phase of senescence. As most of all the earlier culture studies were focused on examining the purported link between iodate reduction and nitrate re- 
ductase, this suggested to us that the differences and contradictions between these earlier experiments may have been related to the duration of the experiments and to the phase of culture growth of the cells during the experiments.

In the present study, we tested whether the different growth phases exhibited different iodate reduction rates. We examined the iodate reduction over longterm culture experiments in which the cells pass through the 5 characteristic phases of growth in cultures (Fogg \& Thake 1987): (1) lag phase, (2) exponential phase, (3) phase of declining relative growth rate, (4) stationary phase, and (5) senescent or declining phase. This work was performed in the laboratory under nitrate replete conditions with 6 different species of phytoplankton (4 Antarctic diatoms, 1 coccolithophore and 1 dinoflagellate), representing coastal and oceanic species from cold to temperate waters.

\section{MATERIALS AND METHODS}

Phytoplankton cultures. Three Antarctic diatom strains, Fragilariopsis kerguelensis, Chaetoceros debilis and Pseudo-nitzschia turgiduloides, were isolated from the Southern Ocean during the iron fertilization ex- periment EIFEX in February/March 2004 by P. Assmy (AWI-Bremerhaven). A fourth Antarctic diatom Eucampia antarctica (CCMP 1452) and the tropical strain of the coccolithophore Emiliania huxleyi (CCMP 371) were obtained from the Provasoli-Guillard Centre for the Culture of Marine Phytoplankton, Bigelow Laboratory, USA. The dinoflagellate Scrippsiella trochoidea was isolated from the southern North Sea in 2001 by U. Tillman (AWI-Bremerhaven). All species were nonaxenic, and their characteristics are listed in Table 1. E. huxleyi, although isolated from the tropical ocean, was cultured under temperate conditions and is referred to here as a temperate species.

Experimental setup. Several experiments were carried out to determine the iodide production mechanism and are listed in Table 2. In general, all species examined were grown in seawater collected from their natural habitat, with nutrients at $f / 2$ concentrations, according to the method of Guillard and Ryther (Guillard \& Ryther 1962, Guillard 1975) The final phosphate and silicate concentrations in the medium were 36 and $106 \mu \mathrm{mol} \mathrm{l}^{-1}$, respectively. Additionally, all diatom species were supplied double the usual silicate concentrations $\left(212 \mu \mathrm{mol} \mathrm{l}^{-1}\right)$ to ensure that silicate is not the limiting nutrient in the culture. Initially, $5 \mu \mathrm{mol} \mathrm{l}^{-1}$ of iodate were added to the culture medium.

Table 1. Species characteristics of the 2 temperate strains and 4 cold water diatoms used in the experiments and their natural distribution. Average values are quoted; $\mathrm{n}>30$. Coccol.: coccolithophorid; dino.: dinoflagellate; cosmopol.: cosmopolitan

\begin{tabular}{|c|c|c|c|c|c|c|}
\hline Phytoplankton species & $\begin{array}{l}\text { Algal } \\
\text { group }\end{array}$ & $\begin{array}{c}\text { Size } \\
\left(\mu m^{2}\right)\end{array}$ & $\begin{array}{c}\text { Volume } \\
\left(\mu \mathrm{m}^{3}\right)\end{array}$ & $\begin{array}{c}\text { Carbon } \\
\left(\text { pg cell }{ }^{-1}\right)\end{array}$ & $\begin{array}{c}\text { Area } \\
\text { volume }^{-1}\end{array}$ & Distribution \\
\hline \multicolumn{7}{|l|}{ Temperate species } \\
\hline Emiliania huxleyi & Coccol. & 47 & 31 & 5 & 1.49 & Cosmopol. oceanic, not polar regions \\
\hline Scrippsiella trochoidea & Dino. & 1335 & 4045 & 581 & 0.33 & Cosmopol. neritic/estuarine, not polar regions \\
\hline \multicolumn{7}{|l|}{ Cold water species } \\
\hline Chaetoceros debilis & Diatom & 90 & 63 & 8 & 1.42 & Cosmopol., mainly cooler waters \\
\hline Pseudo-nitzschia turgiduloides & Diatom & 1168 & 1388 & 102 & 0.84 & Southern cold water \\
\hline Fragilariopsis kerguelensis & Diatom & 1697 & 4677 & 200 & 0.36 & Southern cold water \\
\hline Eucampia antarctica & Diatom & 2711 & 6741 & 276 & 0.40 & Southern cold water \\
\hline
\end{tabular}

Table 2. Overview of experiments. L:D: light:dark cycle; PFD: photon flux density

\begin{tabular}{|c|c|c|c|c|c|c|c|}
\hline Experiments & Species & $\begin{array}{l}\text { Temp. } \\
\left({ }^{\circ} \mathrm{C}\right)\end{array}$ & $\begin{array}{l}\mathrm{L}: \mathrm{D} \\
(\mathrm{h})\end{array}$ & $\begin{array}{c}\text { PFD }(\mu \mathrm{mol} \\
\left.\text { quanta } \mathrm{m}^{-2} \mathrm{~s}^{-1}\right)\end{array}$ & $\begin{array}{c}\text { Iodate } \\
\text { added }(\mu \mathrm{M})\end{array}$ & $\begin{array}{c}\text { Nitrate } \\
\text { added }(\mu \mathrm{M})\end{array}$ & $\begin{array}{c}\text { Nitrate } \\
\text { depletion }\end{array}$ \\
\hline \multirow[t]{2}{*}{$\begin{array}{l}\text { Experiment } 1 \\
\text { (a) Iodide production }\end{array}$} & Temperate & 18 & $12: 12$ & $50 / 100$ & 5 & 88 & No \\
\hline & Cold water & 4 & $16: 8$ & $50 / 100$ & 5 & 88 & No \\
\hline (b) Iodide production & Chaetoceros debilis & 4 & $16: 8$ & 50 & 1 & 44 & Yes \\
\hline \multicolumn{8}{|l|}{ Experiment 2} \\
\hline Metabolites and bacteria & $\begin{array}{l}\text { Pseudo-nitzschia } \\
\text { turgiduloides }\end{array}$ & 4 & $16: 8$ & 50 & 5 & 88 & No \\
\hline \multicolumn{8}{|l|}{ Experiment 3} \\
\hline Dark production & $\begin{array}{l}\text { Pseudo-nitzschia } \\
\text { turgiduloides }\end{array}$ & 4 & $0: 24$ & - & 5 & 88 & No \\
\hline
\end{tabular}


All cultures used were monoclonal, and culture handling was done under a laminar flow hood to prevent any outside contamination. The sample bottles and lids were sterilized via autoclaving, and sterile-filtered (Sartobran 300 capsules with a filter combination of 0.45 and $0.2 \mu \mathrm{m})$ growth media was used. In Expt $1 \mathrm{a}$ the nitrate concentration was lowered to $f / 20$, with a final concentration of $\sim 88 \mu \mathrm{mol} \mathrm{l}^{-1}$. Duplicates of each culture and phytoplankton species were run in parallel. One was exposed to a photosynthetically active photon flux density (PFD) of $50 \mu \mathrm{mol}$ quanta $\mathrm{m}^{-2} \mathrm{~s}^{-1}$ and the other to $100 \mu \mathrm{mol}$ quanta $\mathrm{m}^{-2} \mathrm{~s}^{-1}$. Aliquots were sampled regularly for a total of $55 \mathrm{~d}$ or until cells reached mortality. Growth conditions for each experiment are listed in Table 2.

Expt $1 \mathrm{~b}$ was carried out with a Chaetoceros debilis culture at lower initial iodate and nitrate concentrations of approximately 1 and $44 \mu_{\mathrm{mol} \mathrm{l}}{ }^{-1}$, respectively. After cells used up all nitrate and the photosynthetic efficiency $\left(F_{\mathrm{v}} / F_{\mathrm{m}}\right.$ i description see below) reached a value below 0.3 , a second nitrate addition with a concentration of $f / 20\left(\sim 88 \mu \mathrm{mol} \mathrm{l^{-1 }}\right)$ was performed on Day 24. Sampling frequency was the same as in Expt 1a. Cell-free controls (no phytoplankton cells added) using the same filtered seawater media were run in parallel to each experiment ( $1 \mathrm{a}$ and $1 \mathrm{~b}$ ) under the same lighting and temperature conditions.

An extra control was obtained for Expt 2 by filtering a senescent Pseudo-nitzschia turgiduloides culture (this species was selected based on its performance in the first set of experiments) - initially grown in $88 \mu \mathrm{mol} \mathrm{l}^{-1}$ nitrate and $5 \mu \mathrm{mol} \mathrm{l}^{-1}$ iodate enriched seawater-over a $5 \mu \mathrm{m}$ mesh to remove phytoplankton cells but to retain all dissolved organic matter and bacteria in the water. This was done to see whether metabolites or bacteria have an effect on the conversion of iodate to iodide or if it is exclusively done by the phytoplankton. The filtrate was not re-supplied with nutrients or iodate, as sufficient concentrations still prevailed and sampling was done over a period of $30 \mathrm{~d}$.

Expt 3 was conducted to ascertain whether the conversion of iodate to iodide is light dependent and connected to photosynthesis. Two sets of cultures of Pseudo-nitzschia turgiduloides and Chaetoceros debilis were placed in the dark and sampled over a period of $31 \mathrm{~d}$.

Measured parameters and analytical methods. $\mathrm{Nu}$ trient samples were filtered over cellulose acetate filters (pore size $2 \mu \mathrm{m}$ ), and the filtrate was stored frozen $\left(-20^{\circ} \mathrm{C}\right)$ until analysis. Measurements were performed using standard methods for macronutrient analysis after Grasshoff et al. (1999). Samples for chlorophyll a (chl a) measurements were filtered on glass fibre filters (GF/F-Whatman) and immediately stored at $-20^{\circ} \mathrm{C}$. The frozen filters were placed in polypropylene vials together with $11 \mathrm{ml}$ of $90 \%$ acetone and glass beads ( 2 and $4 \mathrm{~mm}$ ). Thereafter, the closed vials were placed in a cell mill for at least 5 min until the filters were completely homogenized. The vials were then centrifuged at $-5^{\circ} \mathrm{C}(10 \mathrm{~min}$ at $4160 \times g$, and the supernatant was measured fluorometrically with a Turner fluorometer according to the method of Welschmeyer (1994).

The photosynthetic efficiency $\left(F_{\mathrm{v}} / F_{\mathrm{m}}\right)$ (Suggett et al. 2003, Rottgers 2007) of the cells was assessed with a Phyto-PAM phytoplankton analyzer (WALZ). In the present work samples of phytoplankton culture were dark adapted for 30 min before measurement. Optimal values of $F_{\mathrm{v}} / F_{\mathrm{m}}$ lie around 0.4 to 0.6 for phytoplankton cultures, lower values indicate cells under stress from nutrient or iron limitation (Maxwell \& Johnson 2000).

For cell enumeration all cultures except Emiliania huxleyi were preserved with LUGOL's solution at a final concentration of $4 \%$. E. huxleyi was preserved with $0.2 \mu \mathrm{m}$ prefiltered formaldehyde at a final concentration of $1 \%$. All samples were stored at $4{ }^{\circ} \mathrm{C}$ in the dark for subsequent counting. Cells were enumerated using inverted light microscopy (Axiovert 135, Zeiss) according to Utermöhl (1958). Only viable cells that were still auto-fluorescing were counted. The cell size of the different species and groups was determined, and their biovolume was calculated from equivalent geometrical shapes (Hillebrand et al. 1999). The cell volume was then converted to cellular carbon content through carbon conversion equations using a carbon to volume relationship recommended by Menden-Deuer \& Lessard (2000).

Bacterial abundances were determined by flow cytometry according to Gasol \& Del Giorgio (2000). Samples were fixed with $0.2 \mu \mathrm{m}$ prefiltered formaldehyde ( $2 \%$ final concentration) in $5 \mathrm{ml}$ cryovials, deepfrozen in liquid nitrogen after a 30 min dark incubation, and stored at $-80^{\circ} \mathrm{C}$. Before analysis, the thawed samples were stained with SYBR Green 1 (Molecular Probes, final concentration $5 \mu \mathrm{M}$, diluted in dimethyl sulfoxide [DMSO]) for $15 \mathrm{~min}$ in the dark. Samples were run through a FACScalibur flow cytometer (Becton \& Dickinson). Bacterial biomass was calculated from abundance data using a conversion factor of $20 \mathrm{fg} \mathrm{C} \mathrm{cell}^{-1}$ (Lee \& Fuhrman 1987).

Iodine speciation. Samples were filtered over cellulose acetate filters (pore size $2 \mu \mathrm{m}$ ) and, if not measured immediately, stored frozen $\left(-20^{\circ} \mathrm{C}\right)$ until analysis. Iodide was determined by cathodic stripping square wave voltammetry according to the method of Luther et al. (1988), modified by Campos (1997), with a detection limit of from 0.1 to $0.2 \mathrm{nmol} \mathrm{l}^{-1}$ and a precision of better than $5 \%$. Iodate was determined spectrophotometrically by its conversion to the $\mathrm{I}_{3}{ }^{-}$ion with 
sulphamic acid, to remove interference by nitrite and potassium iodide, after the method of Truesdale (1978a). Samples were measured in a $5 \mathrm{~cm}$ cuvette with a 'Unicam' spectrophotometer (UV 300, ThermoForma) at a wavelength of $350 \mathrm{~nm}$. The detection limit of the method is $\sim 20 \mathrm{nmol} \mathrm{l}^{-1}$. Samples were measured in triplicate for both iodide and iodate, and standard deviations were gained from the triplicates measured.
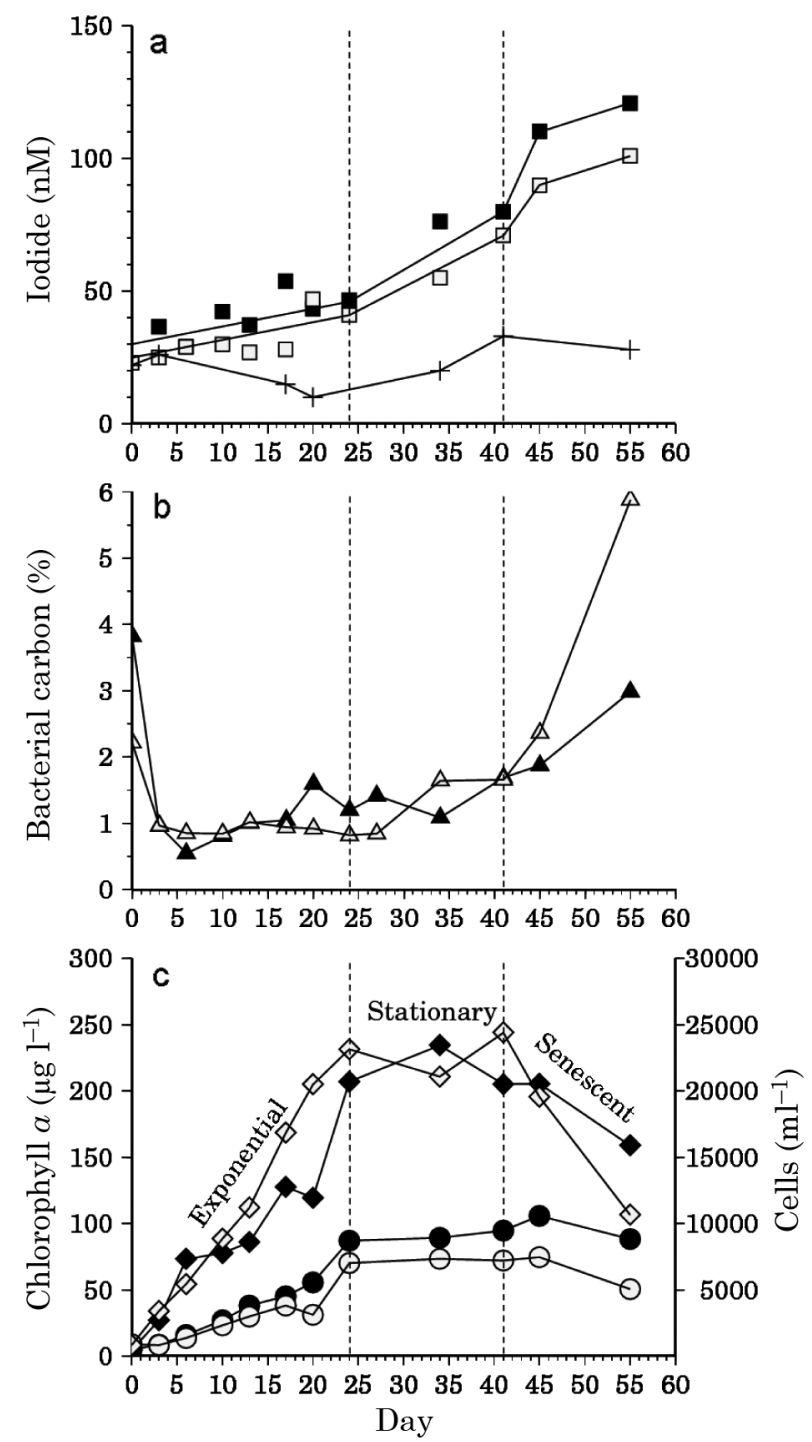

Fig. 1. Fragilariopsis kerguelensis. (a) Iodide production, (b) bacterial carbon and (c) chl a and cell numbers. Bacterial carbon is given as percentage of the total carbon present in the culture flask. Dashed lines: position of the different growth phases; solid symbols: samples grown at $50 \mu \mathrm{mol}$ quanta $\mathrm{m}^{-\mathrm{s}} \mathrm{s}^{-1}$; open symbols: samples grown at $100 \mu \mathrm{mol}$ quanta $\mathrm{m}^{-\mathrm{s}} \mathrm{s}^{-1}$; squares: iodide production; crosses: control without algal cells; triangles: bacterial carbon; diamonds: cell numbers; circles: chlorophyll $a$. Note that the scales for the $y$-axes change for each species. Error bars are smaller than the size of the symbols

\section{RESULTS}

\section{Chl $a$, growth and bacterial carbon}

The changes in iodide production, bacterial carbon, chl a concentration and cell numbers for all species tested are shown in Figs. 1 to 4 . As expected for all species, less chl a per cell was observed in samples grown under the higher light intensity of $100 \mu \mathrm{mol}$ quanta $\mathrm{m}^{-2}$ $\mathrm{s}^{-1}$. The growth phases were identified by visual inspection of the cell count data. The exact time when cells entered a particular growth phase varied between species. The exponential phase, as indicated by a rapid increase in both chl $a$ and cell numbers until a maximum value is reached, lay within the first 8 to $18 \mathrm{~d}$ for most of the species except Eucampia antarctica and Fragilariopsis kerguelensis. Both of these species are slow growing due to heavy silicification and a great
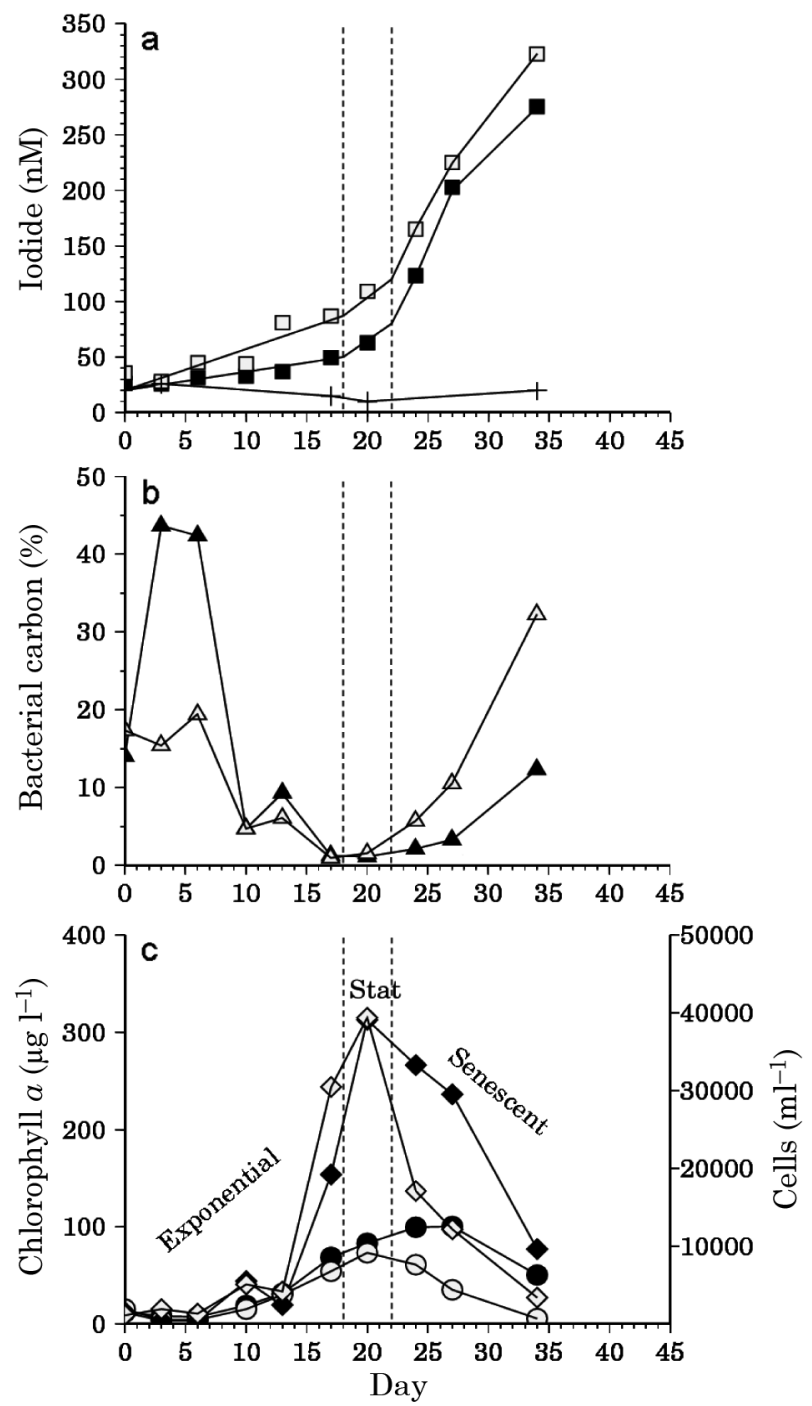

Fig. 2. Pseudo-nitzschia turgiduloides. See Fig.1 for description 

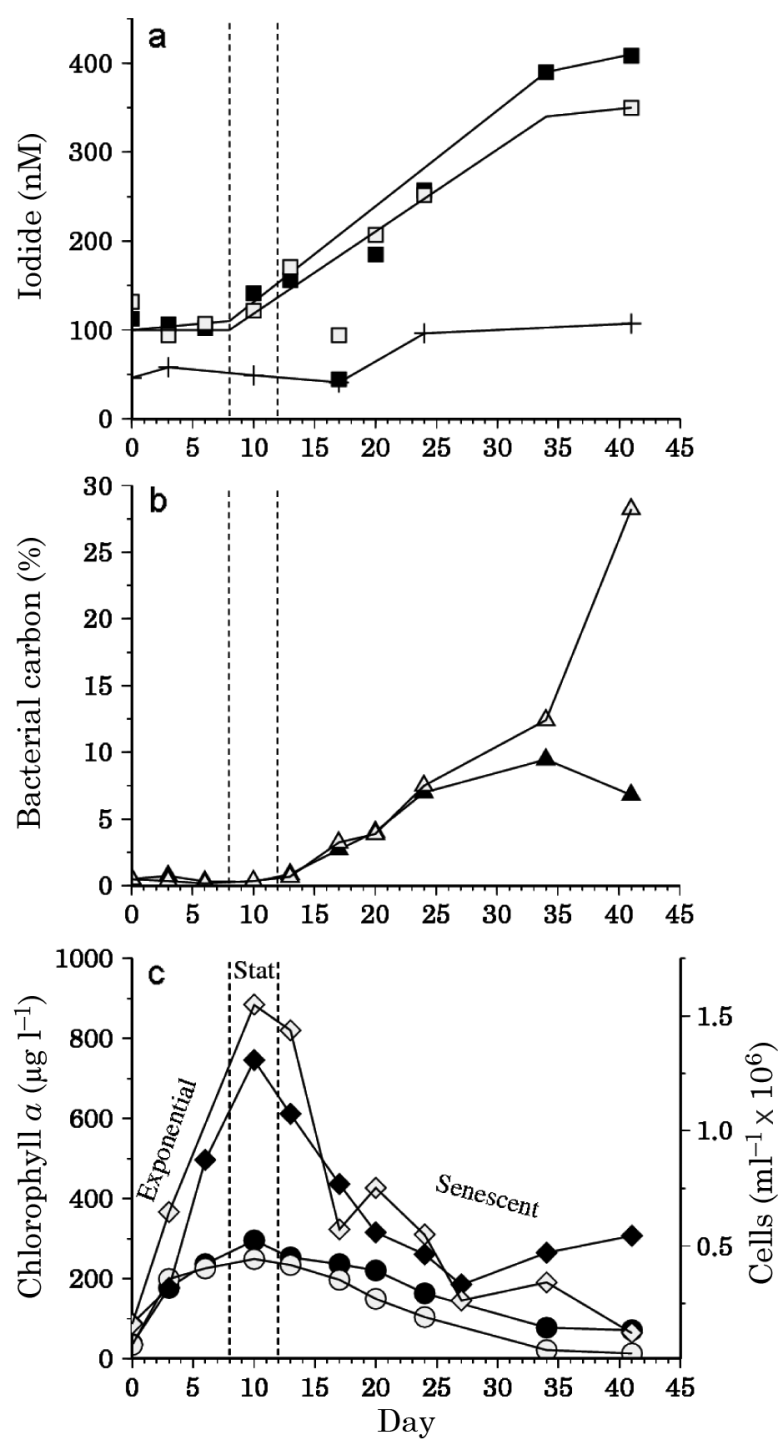

Fig. 3. Emiliania huxleyi. See Fig.1 for description

cell size (Table 1), and their exponential phase continued until Day 24 (Fig. 1C, only shown for Fragilariopsis kerguelensis).

In most species, except Emiliania huxleyi and Pseudo-nitzschia turgiduloides, the stationary growth phase was between 4 and $17 \mathrm{~d}$ long (Figs. 1c \& 4c), whereas in E. huxleyi and P. turgiduloides a distinct stationary phase could not be observed (Figs. 2c \& 3c). Their cell numbers increased exponentially and went straight into senescence after reaching a maximum. This might be due to the timing of sampling, so that we missed the stationary phase, or just their fast-growing behaviour, so that the culture never really entered a stationary phase and went straight from exponential growth to senescence (Figs. 2c \& 3c). Throughout the experiment most of the cultures did not run into nutrient limitation. Nitrate, silicate and phosphate concen-
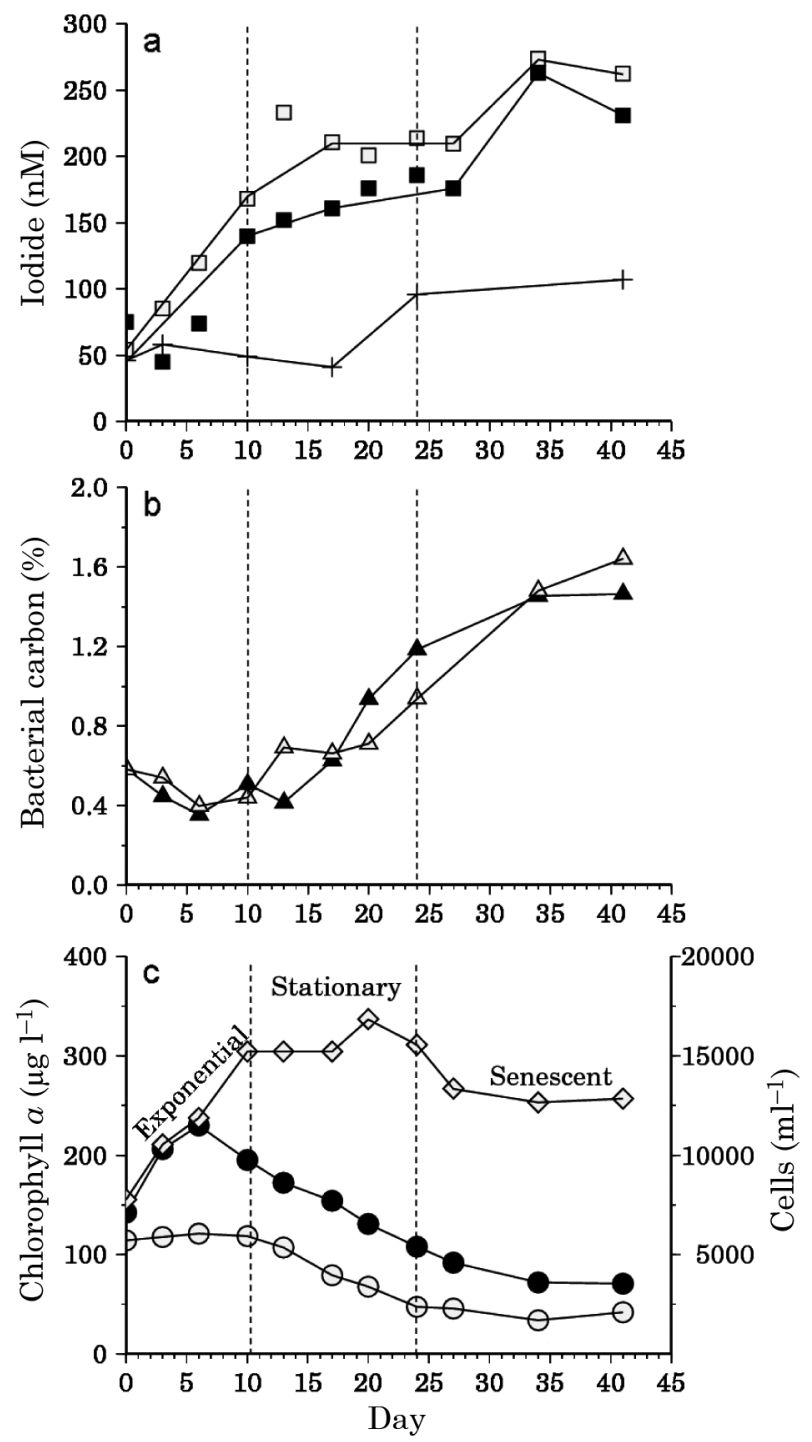

Fig. 4. Scrippsiella trochoidea. See Fig.1 for description

trations were still high when cells reached a senescent growth phase, with $>30 \mu \mathrm{mol} \mathrm{l}^{-1}$ for nitrate, $>60 \mu \mathrm{mol}$ $\mathrm{I}^{-1}$ for silicate and $>23 \mu \mathrm{mol} \mathrm{l}^{-1}$ for phosphate. The only 2 exceptions were Scrippsiella trochoidea, which used up all the nitrate present within $10 \mathrm{~d}$, and Fragilariopsis kerguelensis, which used up all the available silicate and phosphate before cells showed a rapid decline in cell numbers (data not shown).

Elevated iodate levels have sometimes been found to affect phytoplankton growth (Sugawara \& Terada 1967, Zheng et al. 2005) and sometimes without effect (Waite \& Truesdale 2003, Chance et al. 2007). The behaviour and growth of the phytoplankton was not affected by the added iodate. Measured chl $a$ and cell densities appeared similar to untreated samples, and species showed normal growth rates of $\mu=0.11$ to 0.31 cell doublings $\mathrm{d}^{-1}$ (Timmermans et al. 2004) through- 
out the experiments, suggesting that the added iodate neither enhanced nor inhibited cell growth.

Bacterial densities are expressed in bacterial carbon ( $\mu \mathrm{C} \mathrm{C}^{-1}$ ) and are considered in relation to the phytoplankton biomass also expressed in micrograms of carbon per litre. Bacterial numbers in the batch cultures varied between phytoplankton species, but usually were the minor component. Numbers peaked at the end of the experiment and within the senescent growth phase of the phytoplankton (Figs. $1 \mathrm{~b}$ to $4 \mathrm{~b}$ ).

\section{Production of iodide}

Iodide production was only observed in the presence of the algae, with no production in the cell-free controls (Figs. 1a to 4a). In Expt 1, the production of iodide was observed in all species examined. The average iodide production rates per day $(k)$ were estimated as the slope of a linear regression analysis, over the entire duration of the experiment, and the results are listed in Table 3 . The correlation coefficients $\mathrm{R}^{2}$ were always between 0.77 and 0.96 . The amount of total iodide produced over the length of the experiment varied within species from 78 to $302 \mathrm{nmol}$ $\mathrm{l}^{-1}$, and $k$ ranged from 1.25 to a maximum of $7.97 \mathrm{nmol}$ $\mathrm{l}^{-1} \mathrm{~d}^{-1}$ (Table 3). Emiliania huxleyi and Pseudo-nitzschia turgiduloides had the highest $k$ with the greatest amount of total iodide produced relative to the other species.

The rate $k$ was additionally normalised to the socalled 'time-averaged chl $a^{\prime}$; this was done with the trapezoidal method. This method is used to approximate the area under a curve (chl $a$ vs. time curve in this case) by circumscribing $n$ number of trapezoids under this curve. The area of the trapezoids is then summed. This method is used to gain average chl $a$ values for the whole length of the experiment for each species. The same method was used to normalise $k$ to cell densities and is named 'time-averaged cell density' here. According to this method Pseudo-nitzschia turgiduloides was by far the most efficient producer on a chl a basis, with a maximum production rate of $0.26 \mathrm{nmol} \mathrm{l}^{-1} \mathrm{\mu g}^{-1}$ chl $a \mathrm{~d}^{-1}$. All other species revealed lower rates between 0.01 and $0.06 \mathrm{nmol} \mathrm{l}^{-1} \mathrm{\mu g}^{-1} \mathrm{chl} \mathrm{a} \mathrm{d} \mathrm{d}^{-1}$ (Table 3). Production of iodide could be observed in cultures with higher iodate concentrations than naturally found in seawater $\left(5 \mu \mathrm{mol} \mathrm{l}^{-1}\right)$, but also at concentrations close to natural $\left(1 \mu \mathrm{mol} \mathrm{l}^{-1}\right.$; Fig. 5). In Expt $1 \mathrm{~b}$ iodide production was observed in the Chaetoceros species tested. The $k$ rates were comparable to those in Expt 1a, where we added 5 times more iodate.

Table 3. Characteristics of the iodide production rates in cultures of marine phytoplankton. The iodide production rate in Expt $1 \mathrm{~b}$ was only calculated over the time period when nitrate was depleted. Iodate: Initial iodate concentrations added. Iodide: total iodide produced over the course of the experiment. Avg. chl a: time averaged chl a gives an average chl a value for each species. Iodide production rates: rates represent the slope of a linear regression analysis of iodide concentration versus time. $\mathrm{k} / \mathrm{chl} \mathrm{a}$ : is the rate $k$ normalised to time-averaged chl a. Error estimates are at the $95 \%$ confidence interval. $\mathrm{R}^{2}$ : correlation coefficient

\begin{tabular}{|c|c|c|c|c|c|c|c|c|}
\hline Phytoplankton species & $\begin{array}{l}\text { Iodate } \\
(\mu \mathrm{M})\end{array}$ & $\begin{array}{l}\text { Iodide } \\
\text { (nM) }\end{array}$ & $\begin{array}{l}\text { Chl a/cell } \\
\left(\mathrm{pg} \mathrm{cell}{ }^{-1}\right)\end{array}$ & $\begin{array}{l}\text { Avg. chl a } \\
\left(\mu \mathrm{g}^{-1}\right)\end{array}$ & $\begin{array}{l}\text { Iod } \\
\text { Rate }(k) \\
\left(\mathrm{nM} \mathrm{d}^{-1}\right)\end{array}$ & 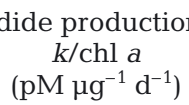 & $\begin{array}{l}\text { n rates }- \\
k / \text { cell } \times 10^{-7} \\
\left(\mathrm{aM} \text { cell }^{-1} \mathrm{~d}^{-1}\right)\end{array}$ & $\mathrm{R}^{2}$ \\
\hline \multicolumn{9}{|l|}{ Expt 1a } \\
\hline \multicolumn{9}{|l|}{ Temperate species } \\
\hline \multicolumn{9}{|l|}{ Emiliania huxleyi } \\
\hline $50 \mu \mathrm{mol} \mathrm{m}{ }^{-2} \mathrm{~s}^{-1}$ & 5 & 302 & 0.29 & 170 & $6.8 \pm 1.6$ & $40 \pm 9$ & $11 \pm 2$ & 0.94 \\
\hline $100 \mu \mathrm{mol} \mathrm{m}{ }^{-2} \mathrm{~s}^{-1}$ & 5 & 256 & 0.19 & 129 & $7.2 \pm 3.6$ & $55 \pm 27$ & $9 \pm 5$ & 0.77 \\
\hline \multicolumn{9}{|l|}{ Scrippsiella trochoidea } \\
\hline $50 \mu \mathrm{mol} \mathrm{m}{ }^{-2} \mathrm{~s}^{-1}$ & 5 & 186 & 9.6 & 122 & $3.4 \pm 1.2$ & $28 \pm 9$ & $265 \pm 89$ & 0.89 \\
\hline $100 \mu \mathrm{mol} \mathrm{m}{ }^{-2} \mathrm{~s}^{-1}$ & 5 & 208 & 6.55 & 67 & $3.4 \pm 1.7$ & $50 \pm 25$ & $296 \pm 149$ & 0.78 \\
\hline \multicolumn{9}{|l|}{ Cold water species } \\
\hline \multicolumn{9}{|l|}{ Chaetoceros debilis } \\
\hline $50 \mu \mathrm{mol} \mathrm{m}{ }^{-2} \mathrm{~s}^{-1}$ & 5 & 166 & 0.47 & 111 & $4.2 \pm 0.8$ & $38 \pm 7$ & $16 \pm 3$ & 0.95 \\
\hline $100 \mu \mathrm{mol} \mathrm{m}{ }^{-2} \mathrm{~s}^{-1}$ & 5 & 142 & 0.29 & 61 & $3.8 \pm 1.1$ & $63 \pm 18$ & $14 \pm 4$ & 0.87 \\
\hline \multicolumn{9}{|c|}{ Pseudo-nitzschia turgiduloides } \\
\hline $50 \mu \mathrm{mol} \mathrm{m}{ }^{-2} \mathrm{~s}^{-1}$ & 5 & 249 & 4.15 & 53 & $7.7 \pm 2.9$ & $146 \pm 54$ & $493 \pm 182$ & 0.81 \\
\hline $100 \mu \mathrm{mol} \mathrm{m}{ }^{-2} \mathrm{~s}^{-1}$ & 5 & 295 & 3.03 & 31 & 8.0. \pm 2.2 & $255 \pm 71$ & $643 \pm 179$ & 0.87 \\
\hline \multicolumn{9}{|c|}{ Fragilariopsis kerguelensis } \\
\hline $50 \mu \mathrm{mol} \mathrm{m}{ }^{-2} \mathrm{~s}^{-1}$ & 5 & 78 & 4.08 & 68 & $1.3 \pm 0.3$ & $18 \pm 4$ & $80 \pm 17$ & 0.92 \\
\hline $100 \mu \mathrm{mol} \mathrm{m}^{-2} \mathrm{~s}^{-1}$ & 5 & 98 & 291 & 51 & $1.5 \pm 0.3$ & $30 \pm 6$ & $93 \pm 19$ & 0.92 \\
\hline \multicolumn{9}{|l|}{ Eucampia antarctica } \\
\hline $50 \mu \mathrm{mol} \mathrm{m}{ }^{-2} \mathrm{~s}^{-1}$ & 5 & 122 & 43.29 & 160 & $2.0 \pm 0.8$ & $12 \pm 5$ & $500 \pm 207$ & 0.80 \\
\hline $100 \mu \mathrm{mol} \mathrm{m}{ }^{-2} \mathrm{~s}^{-1}$ & 5 & 152 & 37.07 & 111 & $2.8 \pm 0.4$ & $25 \pm 4$ & $853 \pm 124$ & 0.96 \\
\hline \multicolumn{9}{|l|}{ Expt 1b } \\
\hline Chaetoceros debilis & 1 & $101 \pm 23$ & - & $63 \pm 1.2$ & $3.5 \pm 0.4$ & $56 \pm 5$ & - & 0.71 \\
\hline
\end{tabular}



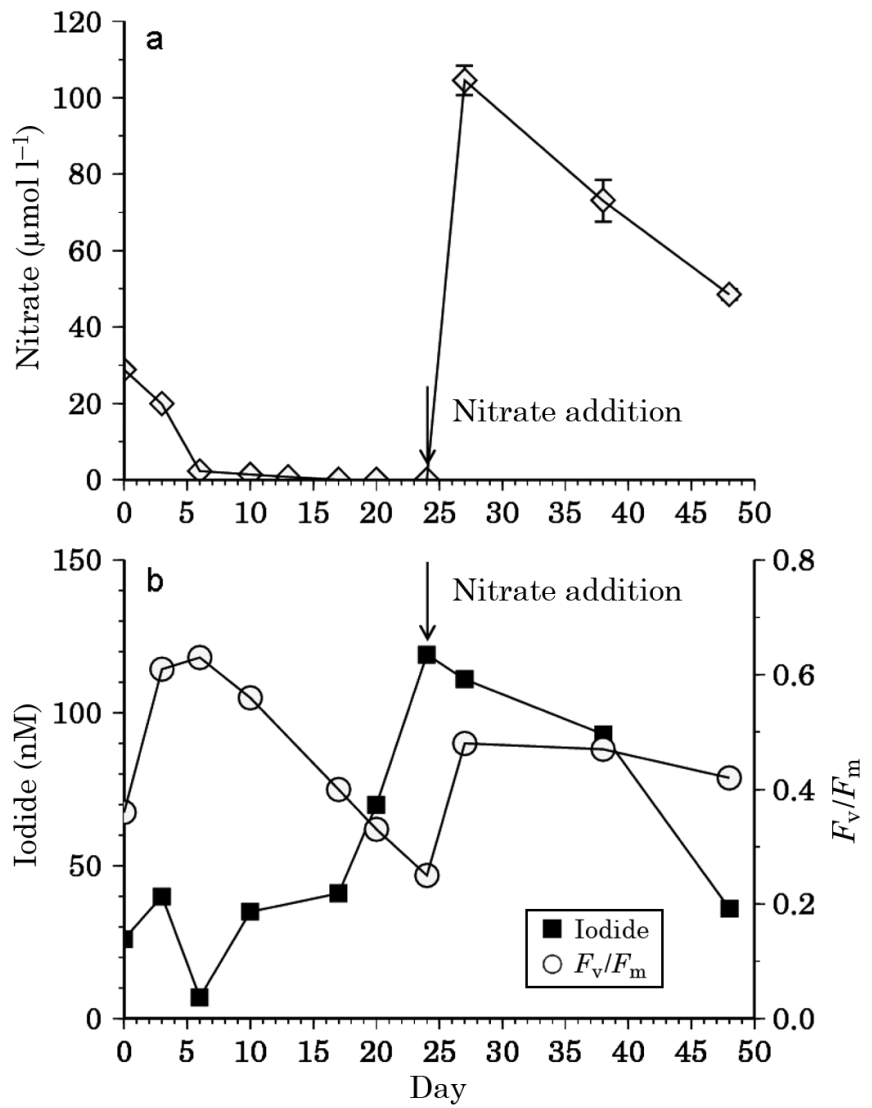

Fig. 5. Chaetoceros debilis. (a) Nitrate, (b) iodide and photosynthetic efficiency $\left(F_{\mathrm{v}} / F_{\mathrm{m}}\right)$ in C. debilis during Expt $1 \mathrm{~b}$. Error bars are smaller than the size of the symbols

\section{Iodide production vs. growth phase}

All species, except Scrippsiella trochoidea, showed the same behaviour when relating the production of iodide to the state of their growth phase (Figs. 1 to 4 , Table 4). During the exponential growth phase no or negligible amounts of iodide were produced; once cells reached the stationary phase, iodide increased rapidly and peaked in the senescent phase. In contrast

Table 4. Duration and growth phase in which iodide production took place in each phytoplankton species

\begin{tabular}{|c|c|c|c|c|}
\hline \multirow{2}{*}{ Phytoplankton species } & \multirow{2}{*}{$\begin{array}{l}\text { Duration } \\
\text { (d) }\end{array}$} & \multicolumn{3}{|c|}{ Phase- } \\
\hline & & Exponential & Stationary & Senescent \\
\hline \multicolumn{5}{|l|}{ Temperate species } \\
\hline Emiliania huxleyi & $8-41$ & No & Yes & Yes \\
\hline Scrippsiella trochoidea & $3-41$ & Yes & No & Yes \\
\hline \multicolumn{5}{|l|}{ Antarctic diatoms } \\
\hline Chaetoceros debilis & $10-41$ & No & Yes & Yes \\
\hline Pseudo-nitzschia turgiduloides & $18-34$ & No & Yes & Yes \\
\hline Fragilariopsis kerguelensis & $24-55$ & No & Yes & Yes \\
\hline Eucampia antarctica & $24-55$ & No & Yes & Yes \\
\hline
\end{tabular}

S. trochoidea, a mixotrophic dinoflagellate, showed an increase in iodide accompanying their exponential phase (Fig. 4).

\section{Influence of nitrate on iodide production}

In Expt $1 \mathrm{~b}$ the lower initial nitrate concentrations of $\sim 44 \mu \mathrm{mol} \mathrm{l}^{-1}$ used in this setup caused a total nitrate consumption in the first $6 \mathrm{~d}$ (Fig. 5a). Over the following $18 \mathrm{~d}$, cells showed a corresponding decline in $F_{\mathrm{v}} / F_{\mathrm{m}}$, whilst iodide concentrations increased with an

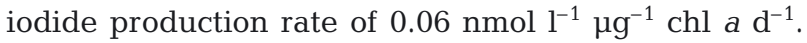
The re-supply of nitrate on Day 24 led to a recovery in the $F_{\mathrm{v}} / F_{\mathrm{m}}$ but a decline in iodide (Fig. 5b).

\section{Depletion of iodate}

Iodate depletion was only observed when iodide concentrations typically exceeded $60 \mathrm{nmol}^{-1}$, and this was due to the combination of high iodate concentrations and the precision of the iodate method (5\%). With the initial iodate concentration of $5 \mu \mathrm{mol} \mathrm{l}^{-1}$, the error on the iodate measurement is $250 \mathrm{nmol} \mathrm{l}^{-1}$. Although, in some species (Emiliania huxleyi and Pseudonitzschia turgiduloides), a corresponding drawdown in iodate concentrations was observable (Fig. 6). Overall, however, a total mass balance was obtained for iodate and iodide throughout the experiments within experimental error, suggesting organic or particulate iodine species were $<20$ nmol $\mathrm{l}^{-1}$ throughout the experiment. Thus, for the remainder of the manuscript, we concentrate solely on the iodide results.

\section{Bacterial influences and dark incubation}

Batch cultures were non-axenic, and the bacterial influences on iodide production needed to be observed. This was examined in Expt 2, where an algalcell-free filtrate control, containing bacteria and phytoplankton exudates of a senescent Pseudo-nitzschia turgiduloides culture, showed no notable iodide production (Fig. 7). Additionally, the iodide concentrations in the dark incubation in Expt 3 did not change over the course of the experiment. Cells showed healthy $F_{\mathrm{v}} / F_{\mathrm{m}}$ values of from 0.4 to 0.5 and were sufficiently supplied with macro- and micronutrients, but did not show an increase in chl a or cell numbers due to the lack of light. 


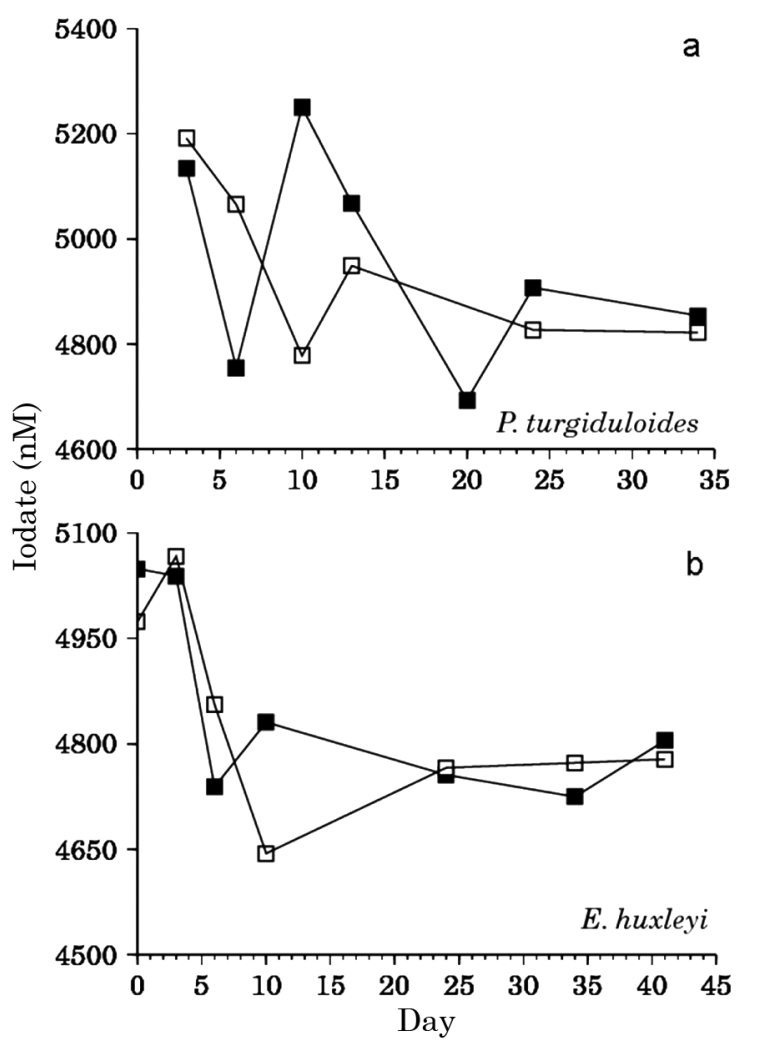

Fig. 6. Iodate depletion in (a) Pseudo-nitzschia turgiduloides and (b) Emiliania huxleyi over the course of the experiment. (घ) samples grown at $50 \mu \mathrm{mol}$ quanta $\mathrm{m}^{-\mathrm{s}} \mathrm{s}^{-1}$; (口) samples grown at $100 \mu \mathrm{mol}$ quanta $\mathrm{m}^{-\mathrm{s}} \mathrm{s}^{-1}$. Error bars are smaller than the size of the symbols. Note that the scales for the $x$ - and $y$-axes are different for each species

\section{DISCUSSION}

\section{Iodide production rates $(k)$ per day}

Iodide production by phototrophs

All species tested produced significant amounts of iodide through the conversion of iodate. Average production rates per day were in agreement with those reported in previous studies (Wong et al. 2002, Chance et al. 2007) and are shown in Table 3. In all cultures, except Scrippsiella trochoidea, the iodide production began in the stationary growth phase (Figs. 1 to 4). Pseudo-nitzschia turgiduloides showed the highest iodide production of all species tested. During RV 'Polarstern' cruise ANTXXIV-3 in March 2008, we found elevated iodide values in the neritic Weddell Sea Zone compared to samples taken further north along the Zero Meridian (K. Bluhm et al. unpubl.). P. turgiduloides has been found to exist predominantly in this region of the southern Polar Ocean (Almandoz et al. 2008).

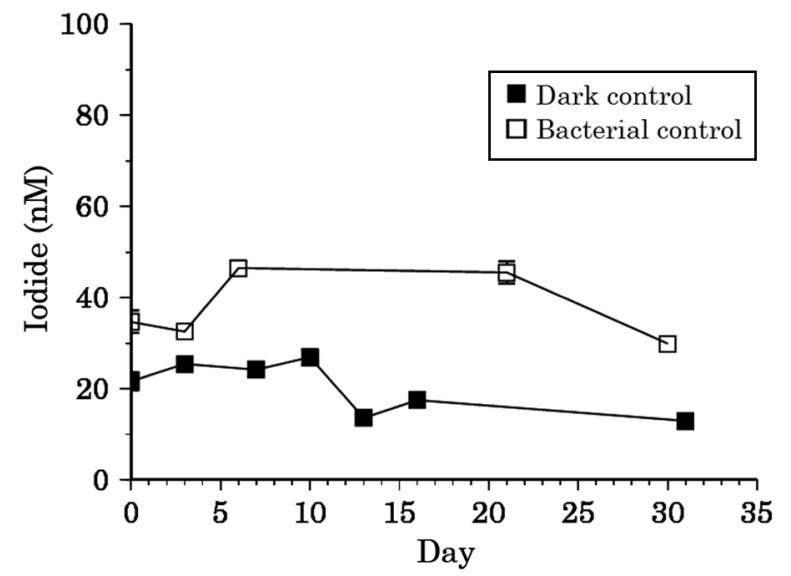

Fig. 7. Pseudo-nitzschia turgiduloides. Bacterial control and dark control of a $P$. turgiduloides culture. Bacterial control: $5 \mu \mathrm{m}$ filtrate of a senescent $P$. turgiduloides culture. Dark control: exponentially growing $P$. turgiduloides culture placed in the dark. See Table 2, Expts 2 and 3

Iodide production by mixotrophs

Scrippsiella trochoidea is a mixotrophic dinoflagellate and able to perform phagotrophy. Phagotrophy is usually the primary nutritional mode in mixotrophic dinoflagellates, as they are only able to reach maximum growth rates phagotrophically (Raven 1997). These species have a high nutrient demand, especially when grown under autotrophic conditions, which was reflected in our experiments by total nitrate consumption within $10 \mathrm{~d}$. Consequently, for mixotrophs, photosynthetic carbon fixation has been interpreted as a survival strategy when food densities are low (Andersson et al. 1989, Sanders et al. 1990). Mixotrophs utilise digestive enzymes to consume organic matter, and it has been demonstrated that this process can be used to assimilate colloidal iron (Maranger et al. 1998). A low $\mathrm{pH}$ environment is required to dissolve colloidal iron, and under such conditions the redox equilibrium between iodide and iodate is shifted towards iodide once the pH is below 5.7 (Sillen 1961). We then suggest that mixotrophs may passively reduce iodate to iodide via the ingestion of seawater when feeding. Interestingly, this would furthermore suggest that protozoans, which have been shown to dissolve iron colloids (Barbeau et al. 1996), may also contribute to iodate reduction in the ocean.

\section{Is the iodide from iodate reduction?}

Two issues were raised during the reviewing process of this manuscript: what was the iodine source of the observed iodide in our experiments, and what possible alternatives are there to iodate reduction? We do not 
believe iodine could stem from any source other than iodate for the following reasons. (1) The concentration of organic iodine in the air is not significant to provide a source of iodide to seawater via air-sea gas exchange (the equilibrium concentrations would be in the range of $0.1 \mathrm{nM}$ ) (Martino et al. 2009). (2) The idea that the cells themselves are a source of iodine to the experiment is valid, but this source is also insignificant to explain the observed changes. Using the canonical I:C mole ratio of Wong et al. (1976) of $\sim 1 \times 10^{-4}$ and the estimated initial $\mathrm{C}$ content of the added phytoplankton biomass at the start of each experiment (range: 90 to $5500 \mu \mathrm{g} \mathrm{C}^{-1}$ ), we derive a mean iodine addition of $3.1 \pm 2.3 \mathrm{nM}$ for the phototrophs and $41 \pm 4 \mathrm{nM}$ for the mixotroph described in the previous section. Thus, in most of the experiments, the cell biomass would have provided insignificant iodine to have caused the observed iodide signal. Only in the case of the mixotroph is it possible that a significant detectable amount of iodine was added to the culture in the form of particulate iodine, but that this is still less than the observed iodide signal. Thus, we conclude that in the absence of a significant additional known source of iodine in the experiment, the observed iodide signal can only have come from reduction of the iodate in solution.

\section{Iodide production rate $(k)$ per cell}

Interestingly, Fragilariopsis kerguelensis produced considerably less iodide per cell $\left(0.86 \times 10^{-7} \mathrm{nmol} \mathrm{l}^{-1}\right.$ cell $^{-1}$ ) compared to its remote relative Pseudo-nitzschia turgiduloides $\left(5.37 \times 10^{-7} \mathrm{nmol}^{-1} \mathrm{cell}^{-1}\right)$, although the latter species is 1.5 times smaller with 3.5 times less cell volume (Table 1). Our initial hypothesis was that, if it was purely a metabolic process by the cells, then the production of iodide per cell should be proportional to some indicator of biomass (cell volume) or cell surface area. However, in the present study, we did not observe any significant relationship between cell volume, or cell surface area, and the amount of iodide produced. We conclude from this that iodide production is species specific and related to some specific physiological process or processes that differ between the phytoplankton examined here.

\section{Iodide production rate $(k)$ based on chl a}

The simple iodide production rates per day $(k)$ were equal in both light regimes in basically all species, but $k$ normalised to chl $a$ was always higher at higher light intensities based on the decrease in chl a per cell (Figs. 1 to 4 , Table 3). Due to a greater light availability, cells may photo-adapt, leading to chloroplasts with less chl $a$, which, however, produce the same amount of iodide per day compared to chloroplasts from cells grown under lower light. Highest rates per chl $a$ were observed in Pseudo-nitzschia turgiduloides $(0.26 \mathrm{nmol}$ $\left.\mathrm{l}^{-1} \mathrm{\mu g}^{-1} \mathrm{chl} \mathrm{a} \mathrm{d}{ }^{-1}\right)$, and this species was a clear example of the processes outlined above (Table 3). Emiliania huxleyi produced iodide with a maximum rate of $0.06 \mathrm{nmol} \mathrm{l}^{-1}{\mu \mathrm{g}^{-1} \mathrm{chl} \mathrm{a} \mathrm{d}}^{-1}$, which is comparable with the findings of Wong et al. (2002), but 4 times lower than those observed by Chance et al. (2007) during their studies. This might be due to divergent calculations of the average chl a concentrations. In our study we used the trapezoidal method, as did Wong et al. (2002), and obtained comparable values. Chance et al. (2007) normalised their values to the simple average $\mathrm{chl}$ a concentration over the selected period. They observed an iodide production in E. huxleyi only in the exponential growth phase of the algae and no production in the stationary phase, with their cells apparently not reaching the senescent phase. This is in contrast to our results for the same species, although a different strain cultured under similar conditions (nutrients and light). However, we suggest that part of the difference may be due to their use of a coulter counter for cell enumeration, which does not distinguish between live and dead cells, unlike epi-fluorescence microscopy. Thus, in their data, the senescence phase does not appear, as cells are still counted even though they may be lacking chloroplasts.

\section{Why was nitrate not totally consumed?}

Some of our cultures apparently did not run into macronutrient limitation (Expt 1a), and, thus, we must look for an alternative reason for the passage into the senescent phase. Physiological death and subsequent lysis of phytoplankton cells have been shown to result from a number of factors apart from nutrient limitation:

(1) Light limitation due to high cell densities in the batch cultures. Nitrate reduction in phytoplankton strongly depends on light energy and will be hampered under these conditions (Berges \& Falkowski 1998).

(2) Changes in alkalinity and pH. Uptake of inorganic carbon by phytoplankton during photosynthesis may increase $\mathrm{pH}$ and cells may become carbon limited as $\mathrm{CO}_{2}$ concentrations decrease under these conditions (Hansen 2002).

(3) Viral lysis. Cells get infected by specific viruses, which induce a loss in the viability of the algal cell and, hence, automortality (Suttle 1992, Bratbak et al. 1998, Nagasaki et al. 2004, Bettarel et al. 2005).

(4) Apoptosis. Autocatalysed cell death, which can be induced by pathogen exposure or through the produc- 
tion of superoxide radicals (oxidative stress) (Antunes et al. 2001, Segovia et al. 2003).

All possibilities mentioned result in cell death followed by a rapid release of cellular constituents to the surrounding medium, which serves as a food supply for bacteria. Consequently, bacterial numbers increase rapidly in this growth phase of the phytoplankton. We suggest here that viral lysis was most likely the reason for cell senescence and cell lysis in our batch cultures, as light limitation, as seen in the dark control experiments, apparently had little effect on cell mortality. Interestingly, light is apparently required for viral replication in some marine phytoplankton, and this may be the reason why the dark control cells remained intact (Baudoux \& Brussaard 2008). Diatoms are relatively insensitive to light deprivation, which is concordant with previous observations that non-spore-forming species such as Thalassiosira weissflogii survive several weeks in good condition (Peters \& Thomas 1996). We did not measure $\mathrm{pH}$ or alkalinity in our cultures, so that we cannot totally rule out that cells might also have become carbon limited, although, with the added nitrate concentrations of $88 \mu \mathrm{mol} \mathrm{l}^{-1}$, cells would have rather become nitrate limited.

\section{Iodate reduction by nitrate reductase}

The enzyme nitrate reductase (NR) has been postulated to perform the reduction of iodate to iodide in phytoplankton and bacteria when nitrate is limiting in the ocean (Tsunogai \& Sase 1969). Our work does not support that view, as our cultures from the first experiment did not run into nitrate limitation although we still observed iodide production. Instead, we believe the reduction of iodate is connected to cell viability and senescence. This also supports the findings of Waite \& Truesdale (2003), who still found iodide production even when NR was deactivated and cells were grown on ammonia instead of nitrogen.

\section{Iodide oxidation to iodate by diatoms}

We did, however, see an interesting effect of nitrate with Chaetoceros debilis (Fig. 5) when iodide production was initiated during cell senescence caused by nitrate limitation. However, upon re-supply of nitrate, iodide production stopped and the concentration declined while cells resumed exponential growth. Thus, an iodide oxidation mechanism must have been active during this time that oxidised $80 \mathrm{nmol} \mathrm{l}^{-1}$ iodide over 25 d. Diatoms have been observed previously to oxidise iodide to iodate (Sugawara \& Terada 1967), and other phytoplankton have been shown to possess iodoperoxidases (Murphy et al. 2000, Hill \& Manley 2009), though these enzymes are normally not capable of oxidising iodide to iodate. A review of the literature on this subject reveals only one reference to a chloroperoxidase in the fungus Caldariomyces fumago that can oxidise iodide to iodate (Thomas \& Hager 1968). Iodoperoxidases are also present in marine bacteria (Gozlan \& Margalith 1973, 1974, Amachi et al. 2005), though none of these studies found oxidation through to iodate. Another possibility would be that iodide had been incorporated into the phytoplankton cells, or lost as $\mathrm{I}_{2}$.

\section{The role of bacteria}

Many phytoplankton cultures are often only available with their associated bacteria; diatoms in particular require the associated bacteria for normal growth (Fukami et al. 1997, Croft et al. 2005, Grossart \& Simon 2007). Therefore, it is difficult to separate phytoplankton responses from those of the surrounding bacteria. Bacteria were present in all cultures to varying amounts; highest numbers were observed in the cultures of Pseudo-nitzschia turgiduloides and Emiliania huxleyi towards the end of the experiment ( $>30 \%$ of total carbon biomass; Figs. $2 b$ \& 3b). The increase in bacteria goes hand in hand with the increase in iodide, and we cannot totally rule out that bacteria also reduce a certain amount of iodate to iodide as they are capable of doing so (Tsunogai \& Sase 1969, Amachi et al. 2007). In all other cultures, bacteria were minor constituents and can be neglected (Figs. $1 \mathrm{~b}$ to $4 \mathrm{~b}$ ). These results are corroborated by the results of the bacteria control experiment (Expt 2) in which no significant changes in iodide were observed (Fig. 7).

\section{Influence of light}

No influence of light on the iodide production in the deployed range (50 and $100 \mu \mathrm{mol}$ quanta $\mathrm{m}^{-2} \mathrm{~s}^{-1}$ ) was observed in Expt 1a, as samples showed similar $k$ rates under both light regimes (Table 3). However, cells that were kept in the dark for several days did not show any iodide production (Fig. 7), indicating that light did have some effect. However, as both Pseudo-nitzschia turgiduloides and Chaetoceros debilis went into a resting phase during which they no longer took up nutrients, iodide production was probably not related to photosynthesis and the highest iodide production occurred when $\mathrm{C}$ fixation was minimal. Cells held in the dark were still viable with $F_{\mathrm{v}} / F_{\mathrm{m}}$ values never dropping below 0.4, which makes us believe that no cell lysis took place. 


\section{The role of cell permeability}

From our experiments it is apparent that part of the high iodide production rates in the later growth phases are related to cell senescence. When cells become extremely permeable under stressful conditions, such as nutrient limitation or viral infection, metabolites will be released back into the surrounding media and can react with the components of that media, including iodate. The release of cellular material can be hastened during this time by direct cell lysis mediated either by viruses (Nagasaki et al. 2004, Bettarel et al. 2005) or apotosis (Antunes et al. 2001, Segovia et al. 2003). In the present study, we cannot determine which process caused the cells to lyse, but evidence that this process was occurring can be found in the decrease in cells containing intact chloroplasts, as observed by microscopy, and the subsequent increase in bacterial numbers, presumably from the release of labile dissolved organic matter (DOM). The release of cellular metabolites, especially reduced sulphur compounds such as sulphide and glutathione (GSH), which are present in high concentrations inside phytoplankton cells (Matrai \& Keller 1994) and are able to reduce iodate to iodide under typical seawater conditions (Hird \& Yates 1961, Jiazhong \& Whitfield 1986), seems to be the most likely cause for the increase in iodide at this time. Our finding is consistent with phytoplankton culture experiments investigating sulphide production (Walsh et al. 1994), during which increases in the dissolved free-sulphide concentration were observed during the senescence phase. Additionally, field work on sulphide in the ocean suggests that metal complexation is important (Cutter et al. 1999) in reducing the extent of the reaction between sulphide and iodate; thus, in phytoplankton cultures in which the metal speciation is dominated by EDTA complexes, we can infer that reduction rates of iodate would be maximal.

Interestingly, our data (Figs. 3 \& 5b) indicate that iodate loss, presumably due to uptake by phytoplankton, preceded iodide production by several days. This suggests 2 possibilities: firstly, that the source of the iodide is from the release of iodide accumulated in the cells prior to cell lysis, or, secondly, that there was a conversion of iodate into another form of iodine (iodoorganics) that was unreactive to our analytical methods and which slowly converted to iodide. Iodo-organics are clearly produced during phytoplankton growth (Brownell et al. 2010), but they have not been found in nanomolar concentrations and, typically, are easily photolysed even by phytosynthetically active radiative light (Martino et al. 2006). The uptake of iodate into phytoplankton cells has been studied recently by de la Cuesta \& Manley (2009), and based on their work we estimated that the cellular uptake of iodate may explain the initial drawdown of iodate. This would also imply that iodate is not reduced prior to uptake by the cell, as we see no evidence for increased iodide concentrations at this time. Once in the cell, however, iodate is most likely reduced to iodide by glutathione or other reduced organic species as indicated above.

Our findings apparently contradict the earlier work of Wong et al. (2002), who found no clear relationship between iodide production and the growth phase of the culture. Indeed, they ruled out cell lysis as a possible cause, though this may have been because they did not measure cell numbers or any proxy of cell permeability. In the present work, we can examine the potential of cell lysis by determining the rate of iodide increase as a function of cell mortality, for time points at which both chl $a$ and cell numbers are decreasing, as a function of the estimated C content per cell, here used as a proxy for $\mathrm{S}$ content (Fig. 8). Our results suggest that, for a first approximation, there is a relationship between $\mathrm{C}$ content and iodide production. Speciesspecific variations in the $\mathrm{S}: \mathrm{C}$ ratios (Matrai \& Keller 1994) may be responsible for the variations in this relationship, though, unfortunately, there are no data available for most of the species we examined here.

\section{Ecological relevance}

In the open ocean, the presence of iodide in the euphotic zone and its oxidation back to iodate in deeper waters are linked to biological activity controlling the cycling of micronutrients like iodine. The data obtained during the present study suggest that the production of iodide is a process connected to cell

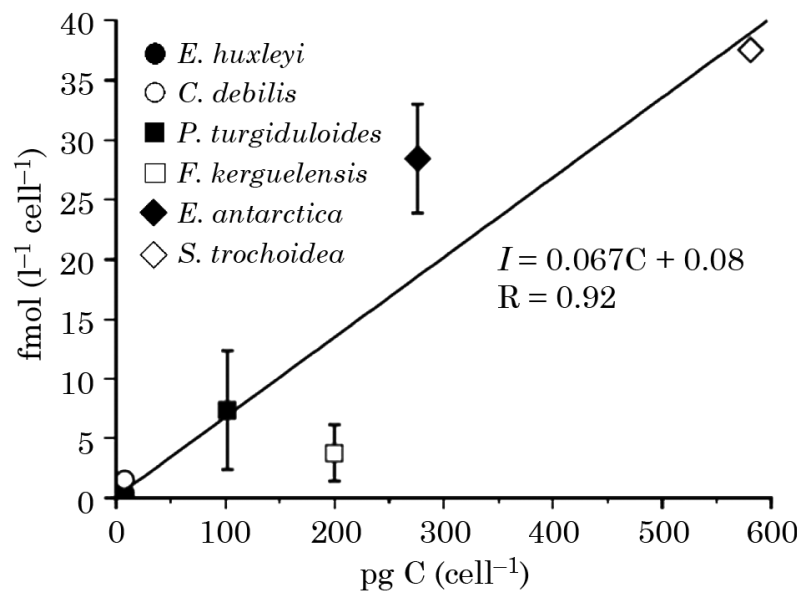

Fig. 8. Calculated iodide production $(I)( \pm \mathrm{SE})$ per dead cell (calculated as the difference in cell numbers between time points) as a function of the estimated $\mathrm{C}$ content per cell. Only data showing both a decrease in chl $a$ and cell numbers after the maximum values were reached are used. For full taxonomic names see Table 1 
senescence and cell permeability, and we speculate that it may be linked to internal sulphur species. If, for example, $10^{5}$ diatom cells $1^{-1}$ - these organisms being present in a range from $10^{4}$ to $10^{6}$ cells $1^{-1}$ in the Southern Ocean (Kopczynska et al. 1986, 1998, Olguin et al. 2006) - produced iodide at a rate we measured for our Antarctic species (average rate: $3.2 \times 10^{-7} \mathrm{nmol} \mathrm{l^{-1 }}$ cell ${ }^{-1} \mathrm{~d}^{-1}$ ), their total iodide contribution would be $0.0316 \mathrm{nmol} \mathrm{l}^{-1} \mathrm{~d}^{-1}$.

\section{Conclusions}

The influence of phytoplankton on the biogeochemical cycle of iodine was investigated in a set of experiments carried out with a variety of phytoplankton taxa. From those results we derive the following conclusions:

In batch cultures of marine phytoplankton the reduction of iodate to iodide is observed, but principally in the late phases of cell growth. The production of iodide is only observable in the stationary and/or senescent growth phase of the algae, the only exception among the mixotrophic species being Scrippsiella trochoidea. In this species iodide production commenced at the very beginning of the experiment.

Cells were grown under nitrate-replete conditions, and it is clear that the reduction of iodate to iodide is not related to nitrate availability, but more to the viability of the cells. Iodine is assimilated by phytoplankton cells preferentially as iodide (de la Cuesta \& Manley 2009), but it still remains unclear whether phytoplankton has an essential metabolic need for iodine. Further investigations are needed to define the role of iodine for phytoplankton needs. The importance of light or nutrient limitation and the resulting senescence in phytoplankton should be observed further in terms of iodide production and the link to $S$ species. A second step would be to examine the behaviour of natural assemblages instead of monoclonal batch cultures.

Acknowledgements. We thank Julia Vasbender and Thomas Hansen (both IFM-GEOMAR) for their help with the phytoplankton counting and flow cytometry analysis, respectively. This work is a contribution to SOPRAN (German SOLAS). Financing was provided through the EU 6th framework project OOMPH (Organics over the Ocean Modifying Particles in both Hemispheres) and DFG SPP-1158 Antarktisforschung (CR145/17 to P.L.C.).

\section{LITERATURE CITED}

Almandoz GO, Ferreyra GA, Schloss IR, Dogliotti AI and others (2008) Distribution and ecology of Pseudo-nitzschia species (Bacillariophyceae) in surface waters of the Weddell
Sea (Antarctica). Polar Biol 31:429-442

Amachi S, Muramatsu Y, Akiyama Y, Miyazaki K and others (2005) Isolation of iodide-oxidizing bacteria from iodiderich natural gas brines and seawaters. Microb Ecol 49: $547-557$

Amachi S, Kawaguchi N, Muramatsu Y, Tsuchiya S, Watanabe Y, Shinoyama H, Fujii T (2007) Dissimilatory iodate reduction by marine Pseudomonas sp. strain SCT. Appl Environ Microbiol 73:5725-5730

Andersson A, Falk S, Samuelsson G, Hagstrom A (1989) Nutritional characteristics of a mixotrophic nanoflagellate, Ochromonas sp. Microb Ecol 17:251-262

> Antunes F, Cadenas E, Brunk UT (2001) Apoptosis induced by exposure to a low steady-state concentration of $\mathrm{H}_{2} \mathrm{O}_{2}$ is a consequence of lysosomal rupture. Biochem J 356: 549-555

Barbeau K, Moffett JW, Caron DA, Croot PL, Erdner DL (1996) Role of protozoan grazing in relieving iron limitation of phytoplankton. Nature 380:61-64

> Baudoux AC, Brussaard CPD (2008) Influence of irradiance on virus-algal host interactions. J Phycol 44:902-908

> Berges JA, Falkowski PG (1998) Physiological stress and cell death in marine phytoplankton: induction of proteases in response to nitrogen or light limitation. Limnol Oceanogr 43:129-135

Bettarel Y, Kan J, Wang K, Williamson KE and others (2005) Isolation and preliminary characterisation of a small nuclear inclusion virus infecting the diatom Chaetoceros cf. gracilis. Aquat Microb Ecol 40:103-114

Boyd P (2004) Ocean science: ironing out algal issues in the Southern Ocean. Science 304:396-397

> Bratbak G, Jacobsen A, Heldal M (1998) Viral lysis of Phaeocystis pouchetii and bacterial secondary production. Aquat Microb Ecol 16:11-16

Brownell DK, Moore RM, Cullen JJ (2010) Production of methyl halides by Prochlorococcus and Synechococcus. Global Biogeochem Cycles 24:GB2002 doi:10.1029/2009 GB003671

Butler ECV, Smith JD, Fisher NS (1981) Influence of phytoplankton on iodine speciation in seawater. Limnol Oceanogr 26:382-386

Campos M (1997) New approach to evaluating dissolved iodine speciation in natural waters using cathodic stripping voltammetry and a storage study for preserving iodine species. Mar Chem 57:107-117

> Campos M, Farrenkopf AM, Jickells TD, Luther GW (1996) A comparison of dissolved iodine cycling at the Bermuda Atlantic Time-Series station and Hawaii Ocean TimeSeries Station. Deep-Sea Res II 43:455-466

> Campos M, Sanders R, Jickells T (1999) The dissolved iodate and iodide distribution in the South Atlantic from the Weddell Sea to Brazil. Mar Chem 65:167-175

Chance R, Malin G, Jickells T, Baker AR (2007) Reduction of iodate to iodide by cold water diatom cultures. Mar Chem 105:169-180

Croft MT, Lawrence AD, Raux-Deery E, Warren MJ, Smith AG (2005) Algae acquire Vitamin B12 through a symbiotic relationship with bacteria. Nature 438:90-93

Cutter GA, Walsh RS, de Echols CS (1999) Production and speciation of hydrogen sulfide in surface waters of the high latitude North Atlantic Ocean. Deep-Sea Res II 46: 991-1010

de la Cuesta JL, Manley SL (2009) Iodine assimilation by marine diatoms and other phytoplankton in nitrate replete conditions. Limnol Oceanogr 54:1653-1664

Egami F, Sato R (1947) Studies on nitrate reductase. I. Bull Chem Soc Jpn 68:39-40 
Elderfield H, Truesdale VW (1980) On the biophilic nature of iodine in seawater. Earth Planet Sci Lett 50:105-114

Farrenkopf AM, Dollhopf ME, Ní Chadhain S, Luther GW, Nealson KH (1997) Reduction of iodate in seawater during Arabian Sea shipboard incubations and in laboratory cultures of the marine bacterium Shewanella putrefaciens strain MR-4. Mar Chem 57:347-354

Fogg GE, Thake B (1987) Cell cycles in culture. In: Algal cultures and phytoplankton ecology. University of Wisconsin Press, Madison, WI

Fukami K, Nishijima T, Ishida Y (1997) Stimulative and inhibitory effects of bacteria on the growth of microalgae. Hydrobiologia 358:185-191

Garland JA, Elzerman AW, Penkett SA (1980) The mechanism for dry deposition of ozone to seawater surfaces. J Geophys Res C 85:7488-7492

Gasol JM, Del Giorgio PA (2000) Using flow cytometry for counting natural planktonic bacteria and understanding the structure of planktonic bacterial communities. Sci Mar 64:197-224

- Gozlan RS, Margalith P (1973) Iodide oxidation by a marine bacterium. J Appl Bacteriol 36:407-417

> Gozlan RS, Margalith P (1974) Iodide oxidation by Pseudomonas iodooxidans. J Appl Bacteriol 37:493-499

Grasshoff K, Kremling K, Ehrhardt M (1999) Methods of seawater analysis, Vol 1. Wiley-VCH Verlag, Weinheim

- Grossart HP, Simon M (2007) Interactions of planktonic algae and bacteria: effects on algal growth and organic matter dynamics. Aquat Microb Ecol 47:163-176

Guillard RRL (1975) Culture of marine invertebrate animals. Plenum Press, New York, NY

- Guillard RRL, Ryther JH (1962) Studies of marine planktonic diatoms. Can J Microbiol 8:229-239

Hansen PJ (2002) Effect of high pH on the growth and survival of marine phytoplankton: implications for species succession. Aquat Microb Ecol 28:279-288

Hill VL, Manley SL (2009) Release of reactive bromine and iodine from diatoms and its possible role in halogen transfer in polar and tropical oceans. Limnol Oceanogr 54:812-822

Hillebrand H, Duerselen CD, Kirschtel D, Pollingher U, Zohary $\mathrm{T}$ (1999) Biovolume calculation for pelagic and benthic microalgae. J Phycol 35:403-424

Hird FJR, Yates JR (1961) The oxidation of cysteine, glutathione and thioglycollate by iodate, bromate, persulphate and air. J Sci Food Agric 12:89-95

Jiazhong Z, Whitfield M (1986) Kinetics of inorganic redox reactions in seawater. 1 . The reduction of iodate by bisulfide. Mar Chem 19:121-137

Jickells TD, Boyd SS, Knap AH (1988) Iodine cycling in the Sargasso Sea and the Bermuda inshore waters. Mar Chem 24:61-82

Kennedy HA, Elderfield H (1987) Iodine diagenesis in pelagic deep-sea sediments. Geochim Cosmochim Acta 51: 2489-2504

Kopczynska EE, Weber LH, Elsayed SZ (1986) Phytoplankton species composition and abundance in the Indian sector of the Antarctic Ocean. Polar Biol 6:161-169

Kopczynska EE, Fiala M, Jeandel C (1998) Annual and interannual variability in phytoplankton at a permanent station off Kerguelen Islands, Southern Ocean. Polar Biol 20: 342-351

Lee S, Fuhrman JA (1987) Relationships between biovolume and biomass of naturally derived marine bacterioplankton. Appl Environ Microbiol 53:1298-1303

Luther GW, Swartz CB, Ullman WJ (1988) Direct determination of iodide in seawater by cathodic stripping square wave voltammetry. Anal Chem 60:1721-1724
Luther GW, Wu JF, Cullen JB (1995) Redox chemistry of iodine in seawater-frontier molecular orbital theory considerations. In: Huang CP, O'Melia CR, Morgan JJ (eds) Aquatic chemistry - interfacial and interspecies processes, Vol 244. American Chemical Society, Washington DC, p 135-155

> Maranger R, Bird DF, Price NM (1998) Iron acquisition by photosynthetic marine phytoplankton from ingested bacteria. Nature 396:248-251

Martino M, Liss PS, Plane JMC (2006) Wavelength-dependence of the photolysis of diiodomethane in seawater. Geophys Res Lett 33:L06606 doi:10.1029/2005GL025424

Martino M, Mills GP, Woeltjen J, Liss PS (2009) A new source of volatile organoiodine compounds in surface seawater. Geophys Res Lett 36:L01609 doi:10.1029/2008GL036334

Matrai PA, Keller MD (1994) Total organic sulfur and dimethylsulfoniopropionate in marine phytoplankton: intracellular variations. Mar Biol 119:61-68

> Maxwell K, Johnson GN (2000) Chlorophyll fluorescencea practical guide. J Exp Bot 51:659-668

> Menden-Deuer S, Lessard EJ (2000) Carbon to volume relationships for dinoflagellates, diatoms, and other protist plankton. Limnol Oceanogr 45:569-579

> Moisan TA, Dunstan WM, Udomkit A, Wong GTF (1994) The uptake of iodate by marine phytoplankton. J Phycol 30: 580-587

Murphy CD, Moore RM, White RL (2000) Peroxidases from marine microalgae. J Appl Phycol 12:507-513

Nagasaki K, Tomaru Y, Katanozaka N, Shirai Y, Nishida K, Itakura S, Yamaguchi M (2004) Isolation and characterization of a novel single-stranded RNA virus infecting the bloom-forming diatom Rhizosolenia setigera. Appl Environ Microbiol 70:704-711

O'Dowd CD, de Leeuw G (2007) Marine aerosol production: a review of the current knowledge. Philos Trans R Soc A 365:1753-1774

> Olguin HF, Boltovskoy D, Lange CB, Brandini F (2006) Distribution of spring phytoplankton (mainly diatoms) in the upper $50 \mathrm{~m}$ of the southwestern Atlantic Ocean $\left(30-61^{\circ} \mathrm{S}\right)$. J Plankton Res 28:1107-1128

Peters E, Thomas DN (1996) Prolonged darkness and diatom mortality. 1. Marine Antarctic species. J Exp Mar Biol Ecol 207:25-41

> Raven JA (1997) Phagotrophy in phototrophs. Limnol Oceanogr 42:198-205

Rottgers R (2007) Comparison of different variable chlorophyll-a fluorescence techniques to determine photosynthetic parameters of natural phytoplankton. Deep-Sea Res I 54:437-451

Saiz-Lopez A, Chance K, Liu X, Kurosu TP, Sander SP (2007) First observations of iodine oxide from space. Geophys Res Lett 34:L12812 doi:10.1029/2007GL030111

> Sanders RW, Porter KG, Caron DA (1990) Relationship between phototrophy and phagotrophy in the mixotrophic chrysophyte Poterioochromonas malhamensis. Microb Ecol 19:97-109

Schonhardt A, Richter A, Wittrock F, Kirk H, Oetjen H, Roscoe HK, Burrows JP (2008) Observations of iodine monoxide columns from satellite. Atmos Chem Phys 8:637-653

Segovia M, Haramaty L, Berges JA, Falkowski PG (2003) Cell death in the unicellular chlorophyte Dunaliella tertiolecta. A hypothesis on the evolution of apoptosis in higher plants and metazoans. Plant Physiol 132:99-105

Sillen LG (1961) The physical chemistry of sea water. In: Sears $M$ (ed) Oceanography. American Association for the Advancement of Science, Washington, DC, p 549-582

> Spokes LJ, Liss PS (1996) Photochemically induced redox reactions in seawater. II. Nitrogen and iodine. Mar Chem 
$54: 1-10$

Sugawara K, Terada K (1967) Iodine assimilation by a marine Navicula sp. and the production of iodate accompanied by the growth of the algae. Inf Bull Planktol Jap 14:213-218

Suggett DJ, Oxborough K, Baker NR, MacIntyre HL, Kana TM, Geider RJ (2003) Fast repetition rate and pulse amplitude modulation chlorophyll a fluorescence measurements for assessment of photosynthetic electron transport in marine phytoplankton. Eur J Phycol 38:371-384

Suttle CA (1992) Inhibition of photosynthesis in phytoplankton by the submicron size fraction concentrated from seawater. Mar Ecol Prog Ser 87:105-112

Thomas JA, Hager LP (1968) The peroxidation of molecular iodine to iodate by chloroperoxidase. Biochem Biophys Res Commun 32:770-775

Tian RC, Marty JC, Nicolas E, Chiaverini J, Ruiz-Ping D, Pizay MD (1996) Iodine speciation: a potential indicator to evaluate new production versus regenerated production. Deep-Sea Res I 43:723-738

Timmermans KR, van der Wagt B, de Baar HJW (2004) Growth rates, half-saturation constants, and silicate, nitrate, and phosphate depletion in relation to iron availability of four large, open-ocean diatoms from the Southern Ocean. Limnol Oceanogr 49:2141-2151

Truesdale VW (1978a) Automatic determination of iodate, iodine and total iodine in seawater. Mar Chem 6:253-273

Truesdale VW (1978b) Iodine in inshore and offshore marine waters. Mar Chem 6:1-13

Truesdale VW (1994) A reassessment of Redfield correlations between dissolved iodine and nutrients in oceanic waters and a strategy for further investigations of iodine. Mar Chem 48:43-56

Truesdale VW, Bale AJ, Woodward EMS (2000) The meridional distribution of dissolved iodine in near-surface waters of the Atlantic Ocean. Prog Oceanogr 45:387-400

Truesdale VW, Kennedy H, Agusti S, Waite TJ (2003) On the

Editorial responsibility: Paul Snelgrove,

St. John's, Newfoundland, Canada relative constancy of iodate and total-iodine concentrations accompanying phytoplankton blooms initiated in mesocosm experiments in Antarctica. Limnol Oceanogr 48:1569-1574

Tsunogai S, Henmi T (1971) Iodine in the surface water of the ocean. J Oceanogr Soc Jpn 27:67-72

Tsunogai S, Sase T (1969) Formation of iodide-iodine in the ocean. Deep Sea Res Oceanogr Abstr 16:489-496

Utermöhl H (1958) Zur Vervollkommnung der quantitativen Phytoplankton Methodik, Vol 9. Science Publishers, Enfield, $\mathrm{NH}$

von Glasow R (2005) Seaweed, iodine, new particles and atmospheric chemistry: the current state of play. Environ Chem 2:243-244

Waite TJ, Truesdale VW (2003) Iodate reduction by Isochrysis galbana is relatively insensitive to de-activation of nitrate reductase activity - Are phytoplankton really responsible for iodate reduction in seawater? Mar Chem 81:137-148

Walsh RS, Cutter GA, Dunstan WM, Radfordknoery J, Elder JT (1994) The biogeochemistry of hydrogen-sulfide: phytoplankton production in the surface ocean. Limnol Oceanogr 39:941-948

- Welschmeyer NA (1994) Fluorometric analysis of chlorophyll$a$ in the presence of chlorophyll- $b$ and pheopigments. Limnol Oceanogr 39:1985-1992

Wong GTF (1991) The marine geochemistry of iodine. Rev Aquat Sci 4:45-73

Wong GTF, Brewer PG, Spencer DW (1976) The distribution of particulate iodine in Atlantic Ocean. Earth Planet Sci Lett 32:441-450

Wong GTF, Piumsomboon AU, Dunstan WM (2002) The transformation of iodate to iodide in marine phytoplankton cultures. Mar Ecol Prog Ser 237:27-39

Zheng WF, Chen CF, Wang YQ, Bao KD, Wang XM, Chu CC (2005) Effects of potassium iodide on the growth and metabolite accumulation of two planktonic diatoms. J Appl Phycol 17:355-362

Submitted: April 30, 2010; Accepted: August 27, 2010

Proofs received from author(s): October 15, 2010 